\title{
Sekularisme en die Gereformeerde se profetiese roeping ${ }^{1}$
}

\section{Floor}

Departement Ou \& Nuwe Testament (Emeritus)

Potchefstroomse Universiteit vir $\mathrm{CHO}$

POTCHEFSTROOM

\begin{abstract}
Secularism and the prophetic calling of the reformed believer

In this arricle the awthor innessigates the phemomenon of seculartsm. Allention is pand to the canse's and (the desirnc'twe) effects of secularism. Three pessible reachons of the church are discussed and queried. i.e. Iradilionalism. polincusm and professiomalism. Another asyect ten kessom(-s) from church history is then considered and the aricle concludes with a few indicators for a possible solution, mumely the necessuly of true Biblical preachung. relevam pastoral comnselling, resyomsible church organusation and the fulfilmem of being prophetic nilliess.
\end{abstract}

\section{Sekularisasie en sekularisme}

Sekularisme is 'n moeilike begrip en dit is bykans onmoontlik om hierdie begrip afgerond te definieer. Die probleem om te kom tot 'n suiwer begripsbepaling word veroorsaak deur die feit dat sekularısme dikwels in een asem genoem word met sekularisasie. Wat die een sekularisasie noem, noem die ander sekularisme en ongekeerd. Elke wetenskaplike het sy eie definisie. In die Duitse taalgebied maak geleerdes onderskeid tussen Säkularısatıon en Säkularismus. Met Säkularısation word die volgende bedoel: 'n Saak of objek wat oorspronklik bestem was vir gebruik in 'n gewyde konteks, word as alledaagse gebruiksvoorwerp binne 'n gewoon-wêreldse raamwerk aangewend. Die saak of objek word as 't ware "onttrek" uit sy oorspronklike (gewyde) betekenis. 'n Kerkgebou word byvoorbeeld verander in 'n skouburg, 'n doopvont word gebruik as 'n drinkbak. Säkularısmus dui volgens die Duitse outeurs 'n geestelike proses aan. In hierdie sin kry die woord die betekenis van 'n lewenshouding los van God: die natuur word byvoorbeeld beskou as iets wat niks te doen het met 'n goddelike skeppingsdaad nie.

I 'n Voordrag gethou by 'n vergadering van dic GTV ic Pretoria op 11 Maart 1996 Deur dic Rudaksic verwerk met instemming van dic outcur 
Gogarten (1953:143) onderskei tussen sekularisasie en sekularisme. Hy sien sekularisasie positief as 'n beweging wat binne die grense van die saaklikheid bly, terwyl sekularisme volgens hom hierdie grens oorskry en ons binne die onsekere buitelyne van 'n ideologie en 'n nuwe mite bring.

Om die begrip sekularisasie te onderskei van sekularisme is ons veilig as ons teruggaan na die geboorte-uur van die begrip sekularisasie. Gedurende die vredesonderhandelinge te Westfalen in 1648 na die Dertigjarige Oorlog is die woord sekularisasie waarskynlik vir die eerste keer deur die Franse gesant Abel Servien gebruik (Rogier, 1968:10). By die verdeling van sekere gebiede in Duitsland is ' $n$ aantal streke gesekulariseer en onttrek aan die mag van die Roomse Kerk. So het sekularisasie die betekenis gekry van onttrekking aan die invloed van die kerk. Toe die begrip sekularisasie in die teologie ingeslaan het, is sekularisasie verstaan as die moderne wêreld se wegkeer van die Christendom. Die begrip het dus ' $n$ negatiewe konnotasie gehad. Op grond van die invloed van Gogarten en Bonhoeffer is egter toenemend ingesien dat daar ook baie positiewe elemente in die sekularisasieproses waargeneem kan word. Sekularisasie beteken in baie gevalle ook bevryding, byvoorbeeld bevryding van bevoogding. Veral onder invloed van Gogarten met sy nuttige onderskeiding tussen sekularisasie en sekularisme is die beweging los van die kerk en los van die Christendom as sekularisme aangedui. Namate verskillende lewensterreine onttrek is aan godsdienstige en religieuse invloed, is hierdie onttrekking beskryf met die begrip sekularisme.

In ons modeme tyd is hierdie proses van sekularisme voluit aan die gang. Die godsdienssosioloog, G. Dekker, beskryf die verskillende prosesse waarvolgens hierdie onttrekking plaasvind baie uitvoerig (Dekker, 1975:101-134).

\section{Watter faktore het sekularisme veroorsaak?}

As oorsake van sekularisme kan die volgende aspekte genoem word:

* tegnologiese ontwikkeling

* matelose selfoorskatting van die wetenskap

* toenemende welvaart

* invloed van die media

* afname van sosiale kontrole

* devaluering van die huwelik

* 'n seksualiteit wat van sy taboe ontslae geraak het

* 'n sterk dinamisering van die samelewing

Die gevolg van bogenoemde faktore is ' $n$ marginalisering van die godsdiens. Godsdiens word meer en meer ' $n$ randverskynsel; religie is nie meer iets wat rus op openbaring nie, maar word net gesien as 'n saak van ervaring. Dit is nic 
belangrik wat jy glo nie - dat jy glo, is al wat van belang is. Die geloofshouding, die fides qua creditur is belangrik. Die geloofsinhoud, die fides quae creditur word gereduseer tot 'n randverskynsel. Bultınann het hierdie gedagte reeds gepropageer en sy leerlinge Fuchs en Ebeling het dit verder uitgewerk (Floor, 1970:99). In werklikheid kom hierdie benadering daarop neer dat iemand 'n Boeddhis kan wees, of 'n Islamiet, of 'n Christen. Die inhoud van die geloof is nie so belangrik nie. Dit gaan om 'n geloofshouding.

\section{Die gevolge van sekularisme}

Sekulansme het - om slegs twee terreine te noem - op die mens en op die kerk 'n geweldige invloed uitgeoefen.

Die Leuvense filosoof, Den Dijn, het daarop gewys dat die sekularisme 'n nuwe mensbeeld geskep het In terme van hierdie mensbeeld staan die gesckulariseerde mens onder die invloed van die postmoderne narsisisme (Den Dijn, 1994:89). Die gesekulariseerde mens is iemand wat net besig is met hounself; hy is nêrens verbind nie: nie met God nie, nie met die wêreld nie, nie met sy medemens nie. Binne die raamwerk van die sekularisme is God dood, daar is geen sentrum van waarheid nie. Ook staan alle vorme van outoriteit onder verdenking, alles is gelykwaardig. Daar kan geen onderskeid gemaak word tussen goed en kwaad, reg en verkeerd, waardevol of waardeloos nie. "Nothing matters, anything goes", is die leuse, relativisme die wagwoord (Lang, 1988:67).

Ook op die kerk is die invloed van sekularisme nie gering nie. Die gevolg van sekularisme is 'n duidelike funksieverlies van die kerk in die samelewing. Baie terreine van die samelewing is gesekulariseer, ontrek aan die invloed van die kerk. Onderwys, kuns, literatuur, politiek, dit is alles terreine waarop die kerk weinig of niks meer kan bereik nie.

\section{Die reaksie van die kerk op sekularisme}

Wat is die reaksie van die kerk op hierdie vloedgolf van sekularisme wat dreig om haar te oorspoel?

Daar is by die kerke oor die hele wêreld (waarby Suid-Afrika ingesluit word) in hoofsaak drie houdings teenoor die voongaande proses van sekularisme

- Die kerk trek hom terug op die terrein van die tradisie

Hierdie houding impliseer dat die kerk hom terugtrek op die vertroude en veilige terrein van die tradisie en redeneer: ons hou vas wat ons van die vaders geleer het. Herdie verskynsel sien ons in die Rooms-Katolieke Kerk en in die Protestantse kerke 
In die Rooms-Katolieke Kerk lei dit in sommige kringe tot 'n herlewing van die ultramontanisme uit die 19de eeu. Die gesag van pous en kerk moet met behoud van die ou kerklike tradisie weer voluit erken word op verskillende terreine van die lewe soos die huwelik, maatskappy en politiek.

In die Protestantse kerke kan dieselfde verskynsel waargeneem word. Dit is opmerklik dat byvoorbeeld in Nederland in verskillende Gereformeerde denominasies soos die Christelijke Gereformeerde Kerken, die Gereformeerde Gemeenten, die Gereformeerde Bond van die Hervormde Kerk 'n sterk verskuiwing na regs plaasvind. Hierdie groepe redeneer: omdat daar in die wêreld soveel verander, mag daar in die kerk niks verander nie. Alles moet dieselfde bly: die kerklike organisasie, die liturgie, die Bybelvertaling, die psalmberyming, selfs kleredrag. Al die veranderings in die wêreld gee baie mense in die kerk 'n gevoel van onveiligheid en onsekerheid. Die ou, gevestigde gebruike in die kerk bring 'n gevoel van veiligheid en rus. Hierdie houding wat in verskillende denominasies dwarsoor die wêreld aangetref word, word deur sommige as veilig en beskuttend beskou. Dit is volgens hulle die enigste doeltreffende wapen teen die invloed van sekularisme. Ander kla egter dat dit verstarring en selfs verstening bewerk

\section{- Die kerk moet die wêreld inbeweeg}

'n Tweede houding is dat die kerk juis nou in die wêreld moet inbeweeg. Met hierdie ingesteldheid word die volgende geïmpliseer: die kerk moet aggresief teenoor die invloed van sekularisme optree, die kerk moet homself manifesteer as 'n maatskappy-kritiese voorhoede; die kerk moet die agenda vir die wêreld skryf, in die liturgie moet dit wat in die wêreld populêr is, opgeneem en verwerk word; die kerk moet krities reageer op wat in die wêreld gebeur.

Ook word gepropageer dat die prediking maatskaplike, sosiale en politieke probleme moet aansny. Die siening word gehuldig dat kerklike formuliere outydse dokumente is wat net nog goed genoeg is om in 'n museum gebêre te word. Baie kerke wat lede van die Wêreldraad van Kerke is, vertoon hierdie beeld. Dieselfde kerke kla egter oor verlies van lidinate: baie lidmate bedank die kerk. Sommige kerke lyk inderdaad soos 'n generale staf sonder soldate: daar is bekwame leiers, goed toegeruste amptenare, 'n groot aantal sosiale en maatskaplike werkers, maar die aanslag op die maatskappy is uiters gering

- 'n Kerk wat professionaliseer

'n Derde houding as reaksie op die proses van sekularisme is die verskynsel van 'n kerk wat professionaliseer Alle heil word verwag vanuit die kader van goed opgeleide professionaliste wat gespesialiseer is in allerlei sosiaal- en gemeenskapsgerigte aktıwiteite. Gemeente-opbou, toerustmg vir 'n taak in 
die wêreld staan op die agenda van die kerk. Dikwels is daar dan sprake van 'n bepaalde gemeente-opbou-model. In die plek van die Bybelse model vir gemeente-opbou is daar ' $n$ organisatoriese en strukturele benadering in gemeente-opbou wat soms ten koste gaan van geestelike opbou en spiritualiteit. So moet die kerk weer 'n werwende, aktiewe gemeenskap wees. Die resultaat is dikwels 'n sterk gesosialiseerde kerk. Die kerk word as't ware 'n Christelik-georganiseerde workshop.

Geeneen van die drie houdings ondervang sekulansme en is by magte om die proses van sekularisme in die samelewing te keer nie.

\section{Die Gereformeerde se roeping}

Wat is die Gereformeerdes se roeping in hierdie tyd van ver deurgevoerde sekularisme? Dr. A.W. Velema wat op hierdie vraag op 'n ampsdraerskonferensie van die Hervormde Kerk in Nederland 'n antwoord gegee het, staan uitermate krities teenoor al die pogings wat aangewend word om deur middel van gemeente-opbou die proses van sekularisme te stuit (Velema, 1996:191-195; 209-211). Hy soek 'n oplossing in 'n ander rigting om die lidmate by die kerk te hou en on die kerk weerbaar te maak teen al die invloede van buite.

Hy wys op twee dinge: pastoraat en liturgie. Hy praat nie van sekularisme nie, maar wys op sekularisasie. Hy aanvaar sekularisasie as 'n positiewe gegewe. Met daardie vertrekpunt gaan hy uit van die standpunt dat die pastor en ook die lidmaat gesekulariseer is. Die gesekulariseerde pastor moet met die gesekulariseerde lidmaat kommunikeer. Eie aarselinge in verband met religie en geloof moet saam deurgepraat word. Dan moet die liturgie die ruimte bied om met al die vrae by God uit te kom. In die ruimte van die liturgie moet ons saam bid om die inspirasie van die Gees. Wat die inhoud van die begrippe pastoraat en liturgie betref, bly Velema vaag. Hoe die inspirasie van die Gees ontvang word en waarin dit bestaan, maak Velema helaas nie duidelik nie.

Die groot vraag is hier watter inhoud word deur pastor en liturg aan pastoraat en liturgie gegee. In verskillende kerke vind ons 'n gesekulariseerde pastoraat en 'n aan die wêreld aangepaste liturgie. Watter antwoorde word gegee op die vrae en aarselinge in verband met religie en geloof? Wat mag ons verwag van die inspirasie van die Gees? Is die Woord hierby ingeskakel of speel dit maar 'n ondergeskikte rol? Die gevaar is dat wanneer die norm van die Woord ontbreek daar ' $n$ spiritualiteit ontstaan wat nie diéselfde is as wat in die Bybel as spiritualiteit aangedui word nie. 


\section{Drie kerkhistoriese aanwysers}

Om 'n antwoord te soek op die vraag na die Gereformeerde se profetiese roeping is dit belangrik om terug te gaan in die kerkgeskiedenis. Ons tyd is nie die enigste tyd wat deur sekularisme gekenmerk is nie. Daar kan in die kerkgeskiedenis drie periodes van duidelike sekularisme in sy oorspronklike betekenis geïdentifiseer word. Tegelyk kan aangetoon word watter antwoord die kerk in daardie tyd op die aanslag van sekularisme gegee het. Hoewel die woord sekularisme nog nie in gebruik was nie, was daar in vroeër tye kerklike en maatskaplike simptome wat ons vandag as sekularisme sou aandui.

\subsection{Die vroeë kerk}

Eerstens is daar die vroee kerk, die kerk van die Apostoliese Vaders. Die eerste eeu van die Christelike kerk was by uitstek 'n tyd van sekularisme. Die godsdiens, sowel die Griekse as die Romeinse godsdiens, was in verval.

Daardie tyd is gekenmerk deur 'n volkome bankrotskap van die religie. Vir eeue lank is die Griekse gode wat op die Olimpusberg sou gebly het, vereer - ten spyte van hul immoraliteit. Hierdie eerbied het algaande verdwyn. Die gode wat hulle aan allerlei ondeugde soos egbreuk, toom, towery en intriges skuldig gemaak het, moes tegelyk die handhawers van geregtigheid wees. Dit het die mense meer en meer tot die gevolgtrekking laat kom dat sulke gode slegs verdigsels is. Die mense het die ou volksgeloof in natuurmagte bly beoefen.

Die Romeinse godsdiens met hulle kontraktuele benadering kon die mense ook nie meer raak nie. Die penate of huisgode was onpersoonlike relekwieë. Die vertroue in hulle gode het by die Romeine drasties afgeneem.

Die reaksie op die bankrotskap van die bestaande religieë was tweevoudig. Aan die een kant het 'n gees van kosmopolitisme in die lewensuitkyk van daardie mense ontstaan - 'n gees wat nogal goed vergelyk met die mense van ons tyd. Die samelewing in al sy vorme is byna geheel onttrek aan die religie. Tog kon godsdiens nie geheel eenkant geskuif word nie. Die mens is immers diep in sy wese religieus. Daar is na 'n ander soort godsdiens gesoek. Die antwoord het uit die Ooste gekom met die opmars van die misteriegodsdienste wat van Oosterse oorsprong is. Dit is opvallend dat - soos in ons gesekulariseerde tyd - die mense soek na ervaring, spiritualiteit. So ook het die mense in daardie tyd die toevlug tot die misterie-godsdienste geneem (Duvenage, s.j.: 24-26)

Ondanks 'n godsdienstige vernuwing het die mensheid egter in daardie tyd weggesink in ' $n$ ontsaglike sedelike moeras. Paulus skilder 'n donker beeld van die sedelike verval van sy tyd in Romeine 1:18-32. 
In 'n tyd soos daardie tree die Christelike kerk op en vervul hy sy profetiese roeping in die samelewing. Wat het die kerk gedoen? Lees maar die geskrifte van die Apostoliese Vaders. In hulle geskrifte staan die praktyk van 'n Christelike lewenswandel sterk op die voorgrond. Dit word telkens aan die orde gestel. Tipiese Christelike elemente soos nederigheid en gehoorsaamheid word onophoudelik benadruk. Die geskrifte van die Apostoliese Vaders het een uitstaande kenmerk: 'n opregte en vurige geloof in Christus (Klijn, 1967:128). Verder is dit opmerklik dat die Christelike lewenswyse voortdurend in verband gebring word met die werk van Christus (Klijn, 1967:130).

Prediking en lewe was in alle opsigte Christus-gesentreerd gewees. Teenoor die buitewêreld kon Christene weerstand bied deur hulle karakteristieke lewenswyse (Klijn, 1967:132). Op die punt van die leer van Christus was daar nie sterk dogmatiese nadenke nie. "The most astonishing feature was the failure to grasp the significance of the death of Christ" (Torrance, 1948:137). Die konsentrasie op die Persoon van Christus was egter indrukwekkend en dit het 'n geweldige impak op die samelewing gehad, soos Von Hamack (1962:147-198) breedvoerig aantoon in sy geskiedenis van die uitbreiding van die Christendom in die eerste drie eeue.

Die heidendom kon nie die kerk binnedring nie, maar die kerk kon wel 'n geslaagde aanval op die wêreld loods.

\subsection{Die kerk van die Reformasie}

In die tyd van die Reformasie was daar 'n religieuse sekularisasie. In terme van vandag sou ons dit sekularisme kon noem. Die Roomse Kerk het wel die hele samelewing beheers, maar op ' $n$ bepaalde manier. Hierdie verskynsel lyk baie na wat in ons land te sien is by die onafhanklike kerke In die tyd voor die Reformasie was die samelewing onttrek aan die gesag van die Woord van God. Die ironie was dat met 'n beroep op die wette van die kerk en die leer van Roine daar 'n romanisering van die samelewing plaasgevind het wat in wese nie veel verskil het van 'n gesekulariseerde samelewing nie. 'n Beeld van die morele en sedelike ontwrigting vall die maatskappy in daardie dae vind ons by Graham (1987:98109)

Wat was kemmerkend vir die Reformasie gewees? Eerstens 'n onvoorwaardelike geloof in die outoriteit van die Bybel. Die Bybel is beskou as die boek van God se openbaring Kerklike wette mag nie oór die openbaring heers nie 'n Hoë premie is geplaas op geloofsekerheid en lewensheiliging.

Al hierdie tendense was egter bepaal en oorheers deur die belangnke en mees kenmerkende ontdekking van die Reformasie: die herontdekking van Paulus, naamlik die geloofsverbondhesd met Christus (vgl. Fil. 1, 21:3, 10) Van 't 
Spijker (1991:114-132) het in sy studie van die Reformatore daarop gewys dat sowel by Luther as by Calvyn en Bucer die unio mystica, die verbondenheid met Christus allesbeheersend was. Calvyn verduidelik dat (hristus exira nos deur die Heilige Gees Christus in nobis word. Van 't Spijker (1991:132) noem die gemeenskap met Christus as vnig van die geloof (effectus fidei) die sentrum van Calvyn se teologie.

In 'n brief aan Petrus Martyr Vermigli waarin Calvyn on 'n nadere verklaring gevra het, werk die Hervormer hierdie gedagte verder uit (Van 't Spijker, 1991:125-127). Deur die geloofswetenskap van Christus in nobis kry ons sekerheid van Christus extra nos. Wanneer Christus in ons woon, vind ons die heil exira nos.

Hierdie teologiese proprium kom in Calvyn se teologie en preke telkens aan die orde, byvoorbeeld in sy siening oor die Nagmaal, sy opvatting oor geloof, wedergeboorte, regverdiging, heiligmaking, uitverkiesing en sy Skrifbeskouing Calvyn het sy opvattings oor 'Christus in ons' vry gehou van mistieke vermenging. Die preke van die Geneefse Hervonner wys voortdurend daarop Ons tref dus weer 'n Christusgesentreerdheid by Calvyn aan. Trouens, Calvyn se persoonlike lewe is gekenmerk deur die vrees van die Here. Die einddoel van al sy denke en handelinge was altyd weer die waaragtige godsvrug in gebondenheid aan die Woord (Praamsma, s.j.:8-9). In sy laaste brief skryf hy: "Dit is vir my genoeg dat ek in Christus leef en sterf" (aangehaal deur Swarz, 1909:478).

By Luther vind ons dieselfde gedagte. Die unio mystica, die verbondenheid met Christus is vir hom allesbeheersend. In Luther se kommentaar op die Psalms fungeer dit as 'n hermeneutiese sleutel.

In De vryhetd van een christen skryf Luther

In de derde plaats is de onvergelijkelijke heerlijkheid van het geloof deze, dat het de ziel verbindt met Christus, als een bruid met haar bruidegom. Christus is vol genade, leven en zaligheid, de ziel is vol van zonden, dood en verdoemelijkheid. Laat nu echter het geloof tussenbeide komen en laat het erop vertrouwen dat van Christus zijn de zonden, de dood en de hel en dat de ziel genade, leven en zaligheid deelachtig wordt. Want het betaamt Hem, zo Hij de bruidegom is, tegelijkertijd die dingen die de bruid heeft, mede mét haar, te aanvaarden en de dingen, die van Hem zijn, aan de bruid mee te delen. Immers hoe zou $\mathrm{Hij}$ die zijn lichaam en zichzelf geeft, niet alles wat het zijne is geven? (Luther, 1959:144-145).

Ook Bucer wys in sy geskrifte voortdurend op die praesentia realis, die inwoning van Christus in ons harte deur die regeneratio (Van 't Spijker, 1991:90). 
Met hierdie oortuiging het die kerk in die tyd van die Refonnasie na buite getree. So het sy haar profetiese roeping in die samelewing vervul (Graham, 1978:97115). McGrath (1990:221-231) het in sy studie van Calvyn en die Calvinisme die inaatskaplike, ekonomiese en politieke relevansie van hierdie geloofsoortuiging treffend aangetoon

Tegelyk wys McGrath (1990:297) egter daarop dat ook die Calvinisme vatbaar is vir sekularisme. Dit gebeur wanneer ons as Gerefonneerdes die religieuse kem van die Calvinisme, naamlik die imige geloofsgemeenskap met Christus gaan verloor. Dan bly daar net 'n residu oor van politieke, sosiale en ekonomiese waardes.

\subsection{Dic Puriteine}

Die derde kerkhistoriese voorbeeld vind ons by die Puriteine. Die geskiedenisboeke vertel ons dat die 17de en 18de eeu in Engeland en Skotland 'n tyd was van diep maatskaplike en sedelike verval. Immoraliteit was aan die orde van die dag, godsdiens was nie in tel nie. Die lewe van elke dag was volkome gesekulariseer. In 'n artikel van Lloyd-Jones "The state of the nation" kan daaroor een en ander gelees word (Lloyd-Jones, 1991:123-147).

Toe kom die Puriteine. Wat was kenmerkend vir hulle teologie en prediking? Weer eens die sterk beklemtoning van die band met Christus. As die band met Christus nie by die gemeente aanwesig is en versterk word nie, sal die kragte van ongeloof sterker word. Die Puriteine het die kruis van Christus sentraal gestel Hulle benadruk voortdurend dat dit nie genoeg is om uiterlike wangedrag te bestry nie. Ons moet ons sondes nie alleen met die wet van God konfronteer nie, maar bo al met die kruis van Christus. Hoe dieper ons insig in die lyding van Christus is, hoe gouer gaan ons ons sondes raaksien.

Binne hierdie konteks vind ons by die Puriteine 'n sterk beklemtoning van die stryd teen die sonde en dan nie in die eerste plek die sonde buite ons nie maar die sonde in ons. Hulle wys in hulle preke dikwels op Paulus se prediking dat ons deur die Gees die werke van die liggaam moet doodmaak (Rom. 5:13). Ons moet die lede wat op die aarde is, doodmaak (Kol. 3:4). Die Puriteine wys in navolging van die Refonnatore op die mortificato (die doding van die vlees met sy hartstogte en begeertes) en die vivificalio (die lewendmaking, die opwekking tot 'n nuwe lewe)

Dan is daar by die Puriteine die beklemtoning van die noodsaak van wedergeboorte. Ook gee hulle baie aandag aan geestelike groei, die groei in heiligmaking. Daar was by hulle 'n diepe besef van die heiligheid van God en as gevolg daarvan 'n groot afkeer van die sonde 
Hierdie benadering het 'n groot invloed op die volkslewe in daardie tyd gehad. Daar het deur die prediking en leefwyse van die Puriteine 'n sosiale en maatskaplike omwenteling plaasgevind.

Wat ons by Paulus lees (Fil. 1:21; 3:10) en in die kerkgeskiedenis opval, is veral die konsentrasie op Christus - sowel in verkondiging as in pastoraat en persoonlike geloofsbelewing.

\section{Hoe Gereformeerd is ons vandag?}

Wanneer ons nou nader beweeg aan die eintlike tema: ons roeping as Gereformeerdes dan moet eers die volgende vrae gevra word: wat is Gereformeerd en hoe Gereformeerd is ons vandag nog?

Kempunte van Gereformeerd-wees sluit die volgende aspekte in:

* die belydenis van die soewereiniteit van God

* die erkenning van die goddelike gesag van die Skrif

* die handhawing van die Fonnuliere van enigheid

* die aanvaarding van die leer van die uitverkiesing

* die beklemtoning van die noodsaak van die wedergeboorte

* die geloof in die plaasvervangende offer van Christus

* die aanvaarding van die leer van die Heilige Gees wat ons die geregtigheid en die heiligheid van Christus deelagtig maak.

Wanneer ons ons kerke en onsself hieraan toets, dan mag die vraag gevra word: beantwoord ons as Gereformeerdes aan hierdie norm? Ons moet ons nie verbeel dat sekularisme by ons kerkdeur uit is nie. Laat ons ons Gereformeerd-wees eers toets aan bogenoemde kenmerke.

Ek wil op drie dinge wys: die prediking, die pastoraat en ons kerklike organisasie.

\subsection{Die prediking}

Dit is baie moeilik om 'n algemene oordeel te gee oor die prediking in die Gereformeerde Kerke en om vas te stel hoe Gereformeerd die prediking is. Tog is daar wel 'n toetsingsmoontlikheid. Hoe staan dit met die Kategismusprediking? Dit lyk of die Kategismus in diskrediet geraak het. Juis hierdie Belydenisskrif help predikante om Christusgesentreerd die Woord te verkondig. Saam hiermee gaan die vraag: watter Christusbeeld word vanaf Gereformeerde kansels aan die gemeente voorgehou? Funksioneer die klassieke Christologie nog in ons verkondiging of word alleen gewys op Jesus wat met ons saamgaan, wat ons opvang, wat gereed staan om bystand te bied, wat die groot Voorbeeld is wat nagevolg moet word? 
Die Christusprediking van die Apostoliese Vaders, die Reformatore en die Puriteine is ook gekenmerk deur die verkondiging van Bybelse begrippe wat nou daannee samehang: die nadruk op wedergeboorte, die heenwysing na die oordeel wat kom, die sterk beklemtoning van die heiligmaking. Dit bring ons by die vraag of die Bybelse temas soos die oordeel, die geng van God, die skrik van die Here wel van ons kansels verkondig word. Soms klink dit of die hel eenvoudig uit ons gesigsveld verdwyn het. Ons bely dit alles met die mond met behulp van die Formuliere van enigheid. Maar laat ons in die konkrete praksis van die verkondiging hierdie stoere klanke ook hoor?

\subsection{Die pastoraat}

Wanneer ons kyk na die pastoraat dan is daar weer dieselfde probleem. Dit is onmoontlik om 'n algemene oordeel te gee oor die beoefening van die pastoraat in die Gerefonmeerde Kerke. Die indruk is egter dat die pastoraat in 'n groot mate sirkel rondom die Nagmaal. Dit is lofwaardig dat in die meeste gemeentes lidmate met die oog op die Nagmaal besock word. Maar byna alle ouderlinge hoor op huisbesoek - soos op kerkraadsvergaderinge gerapporteer word - die eentonige mededeling dat die lidmate 'n hartlike begeerte het on Nagmaal te gebruik. Is dit nie karakteristiek vir die Gereformeerde Kerke dat hulle Nagnaalkerke is nie? Histories is dit verklaarbaar. Groot afstand en gebrekkige vervoermiddele het dit in die hand gewerk dat in die loop van die tyd die Nagmaalsondag by uitstek dié Sondag in die kerklike jaar geword het waarop alle lidmate kerk toe gekom het Ons tyd met sy verhoogde mobiliteit bied nie meer 'n verskoning om vall die kerk weg te bly nie. Hoe word die Nagmaal egter gevier en belewe? Waar is die lidmate wat so begerig is on Nagmaal te gebruik by die nabetragtingsdiens en die volgende Sondae?

Dit laat die vraag ontstaan of die Nagmaalsviering vir baie lidmate nie eerder 'n kerklike ontmoeting as 'n Christusontmoeting geword het nie? Dit skep die indruk dat vir baie die geloof 'n vanselfsprekenheidsgeloof, 'n kerkgeloof, 'n boekgeloof, 'n konfessiegeloof is en nie 'n Christusgeloof nie. Christus se persoon en werk is slegs 'n pro memorı-pos. Hy is op die agtergrond geskuif.

\subsection{Die kerklike organisasie}

Ons mag nie sê dat kerklike organisasie nie 'n goeie ding is nie. Daar kan gewys word op die baie Bybelstudiekringe wat daar is, die Bybelskool-inisiatiewe wat op baie plekke ontplooi word, die persoonlike toewyding van predikante, ouderlinge, lidmate wat 'n mens met blydskap en dankbaarheid vervul.

Tog lyk dit of ons kerklike organisasie nie baie help on ons roeping as Gereformeerdes uit te leef nie. Ons kerk vertoon na buite die beeld van ' $n$ tipiese predikantekerk. Daar is byvoorbeeld geen kurator wat 'n ouderling is nie In die 
moderamina van Klassisse, Partikuliere Sinodes en Nasionale Sinodes figureer alleen predikante. Ook skep die Gereformeerde Kerke die indruk van 'n deputatekerk. Dit is egter positief dat ook lidmate en selfs vroue as deputate funksioneer. Die kerk is baie goed georganiseer, maar is ons wel voldoende gewapen teen die invloed van die sekularisme? In plaas daarvan om as kerk deur middel van sy lidmate die wêreld in te beweeg, is die wêreld besig om in die kerk in te beweeg.

Een van die groot gevare wat die kerk bedreig, is die oorwaardering van die wetenskap ten koste van die geloof. Ons moet die invloed van die Verligting, die rasionalisme en die postmodernisme nie onderskat nie. Daar is, om net cen ding te noem, die groot bedreiging dat ons as gevolg van wetenskaplike ontwikkeling en vermeerdering van kennis meer nadruk lê op die verstand as op die geloof. Daar word geìnpliseer dat aan die Christelike geloof getwyfel mag word, maar nie aan die verstand nie. Die gevolg is dat daar meer aandag gegee word aan die intellek as aan die ware geloof, die persoonlike verhouding tot Christus

Die gevaar is dan groot dat meer klem op die rede gelê word as op die openbaring. Die menslike rede mag nie die openbaring oorheers nie. Dit sien ons by die Verligting en by die histories-kritiese metode van Bybelondersoek. Die klem word deur middel van hierdie metode eensydig sterk gelê op wetenskaplike ondersoek. Hoe belangrik en onontbeerlik wetenskaplike ondersoek ook al is, die verhouding openbaring-rede moet in die regte perspektief gesien word.

Die menslike rede is 'n pragtige instrument wat God ons geskenk het. Deur die Gees verlig kan ons deur middel van die rede God se stem verneem. Die rede kan egter nooit norm of bron wees nie.

Die Gereformeerde teologie aanvaar God se openbaring as norm. Kerklike organisasie, hoe goed ook al gereël, en verstandsgodsdiens kan nie die invloed van sekularisme keer nie.

\section{Die vervulling van ons profetiese roeping}

Die eerste Christene, die gelowiges in die tyd van die Reformasie en die Puriteine het deur hulle optrede in die wêreld gewys aan Wie hulle behoort en wat hulle tot hulle Christelike dade gedryf het. By almal van hulle was daar 'n sterk Christuskonsentrasie.

Wat by die Apostoliese Vaders, by die Reformatore en by die Puriteine so kenmerkend was, kan die beste tot uitdrukking gebring word met die OuTestamentiese term: die vrees van die Here, die Jerath Jawhe. 
Die vrees van die Here het in sy verhouding tot God en in sy verhouding tot die samelewing die volgende komponente:

- Die verhouding tot God impliseer altyd die besef van God se grootheid en heiligheid.

- Die vrees van die Here word gekenmerk deur aflıanklıkheid en aanhanklikheid (Oosterhoff, 1949:125-127).

In horisontale verhoudinge werk die vrees van die Here 'n besef van regverdigheid, mensliewendheid, betroubaarheid, diensvaardigheid en selfverloëning (Oosterhoff, 1949:131-132).

Ons moet ons profetiese roeping vervul vanuit 'n op Christus gekonsentreerde geloofslewe. Hoe gaan ons dit in die praktyk in 'n gesekulariseerde samelewing toepas? In dic eerste plek moet ons aanvaar dat die verhouding tussen kerk en staat, die invloed van die gemeente van Christus op die samelewing nie 'n direkte verhouding is nie, maar 'n indirekte. In die tweede plek het die kerk die profetiese roeping en die belangrike opdrag om in die prediking, toerusting en gemeente-opbou Christus te verkondig en die gemeenskap met Christus te bevorder.

Die kerk moet die gelowiges toerus vir hulle getuienis in die samelewing, om 'n profeet te wees in die oortuiging dat die kerk die antwoord het op die probleme van ons tyd. Dan is dit egter absoluut noodsaaklik dat Christus vir ons 'n lewende werklikheid is, dat ons die gemeenskap met Hom belewe.

McGrath (1992:143) skryf dat alleen die ortodokse Christendom die apologetiese en geestelike middele besit on die verlore terrein in die wêreld weer terug te win. Onder 'n ortodokse Christendom verstaan hy dan kerke en Christene wat weet van 'n Christusontmoeting en Christuservaring. Sondag 12 van die Heidelbergse Kategismus spel dit so duidelik uit: "Ek is deur die geloof 'n lid van Christus Daardeur het ek deel aan sy salwing, sodat ek sy Naam kan bely."

Samevattend kan alles kortliks só gefonnuleer word: ons profetiese roeping as Gerefonneerdes om die invloed van die sekularisisme in die kerk en buitekant die kerk hok te slaan, is eenvoudig die ware belewing van wat in die Ou Testament genoeın word die vrees van die Here, die Jerath Jahwe. God vra van ons in 'n tyd soos hierdie om in diep afhanklikheid vau Christus en opregte aanhanklikheid aan Hom te leef in die besef van sy heiligheid en majesteit.

Herman Bavinck het kort voor sy dood, toe daar in die Gerefonnecrde Kerken in Nederland spanning ontstaan het tussen konserwatiewes en verligtes en die vraag na die roeping van die kerk in die wêreld aktueel geword het, gewys op wat hy in 
die kerk met betrekking tot haar roeping in die wêreld die hoofsaak noem: "De persoonlijke band des geloofs aan de levende Christus" (Graafland, 1995:63).

\section{Bibliografie}

DEKKER, G 1975. De mens en zijn godsdienst Beschouwingen over de functies van godsdienst en kerk voor mens en samenleving Bilthoven : Ambo

DEN DIJN, H 1994 Hoe overleven wij de vrijheid modernisme, post-modernisme en het mystieke lichaam. Kappellen : Pelckmans

DUVENAGE, S.C.W. sj Die dekor van die Nuwe Testament. 'n Kultuurhistoriese agtergrondstudie Pretoria : Interkerklike Uitgewerstrust

FLOOR, L 1970. Calvyn se hermeneutiek in vergelyking met Ebeling en Fuchs Neorestamentica, 4:94-107.

GOGARTEN, F 1953. Verhangenis und Hoffnung der Neuzeit Die Säkularisierung als theologisches Problem Stuttgart : Friedrich Vorwerk Verlag.

GRAAFLAND, C 1995 Als Bavinck maar eens kleur bekende Radix. Gereformeerd Interfacultair Tijdschrift, 21(2), April

GRAHAM, WF 1978 The constructive revolutionary John Calvin His socio-economic impact Atlanta John Knox Press

KLIJN, A.F.J 1967. Apostolische vaders 3 Baarn. Bosch en Keuning

LANG, C.C D 1988 Irony/humor: critical paradigms Daltimore John Hopkins University Press.

LLOYD-JONES, M 199]. The state of the nation (In Unity in truth Darlington : Evangelical Press )

LUTHER, M 1959 De vrijheid van een christen. (In Luthers werken Kooijman W J red Kampen : Kok )

McGRATH, AE 1990 Johannes Calvijn Verlichte hervormer of vormgever van een orthodox keurslijf? Baarn : Tirion

McGRATH, AE 1992 Bridge-building Leicester University Press

OOSTERHOFF, B J. 1949. De vreze des Heren in het Oude Testament. Utrecht Kemink.

ROGIER, L J 1968 De historische achtergrond van de secularisatie (In Puchinger, G red. Christen en secularisatie Delf Meinema p. 9-33.)

SWARTZ, R 1909 Johannes Calvins Lebenswerk in seinen Briefen 1 Tubingen Mohr

TORRANCE, TF 1948 The doctrine of grace in the Apostolic Fathers Edingburgh/ London : Marshall, Morgan \& Scott

VAN 'T SPIJKER, W 1991 'Extra nos' en 'In nobis' bij Calvijn in pneumatologisch licht (In Augustijn, C. Neuser, WH \& Selderhuis, H J red Geest, Woord en Kerk Opstellen over de geschiedenis van het gereformeerd protestantisme Kampen : Kok p 114-132.)

VELEMA, A W 1996 Pastoraat in een geseculariseerde samenleving De Wekker 105, Jan 26 en Febr 2. 
VON HARNACK, A 1962 The mission and expansion of Christianity in the first three centuries New York : Harper \& Brothers 
